\title{
Celebrities and Influencers: Have They Changed the Game of Online Marketing?
}

\author{
Tariq Mehmood Dar and Neelofer Tariq
}

\section{ABSTRACT}

Online marketing is termed as marketing 2.0 , mainly because the ' 2 ' here indicates how much double the marketing provides. Doubling in terms of profits, customers reach, and most importantly, brand image. Thereby, the dilemma arises where most of the brands, often even after having the right quality products, fail to satisfy their customers or, in the other case, fail to grow the virtual communities of their target audience. However, the following review article entails all the information needed regarding influential marketing \& celebrity endorsements. Thus, to give marketers a new hope and scope in their blank world of Online Social networks.

The paper contains an extensive literature review of 20 peer-reviewed articles published in reputable business journals. These consist of valuable details regarding the dos and perks of optimizing celebrity endorsements and influential marketing.

Moreover, proceeding to the review portion, recommendations have been incurred to further benefit the readers \& provide them a fresh insight into the two dilemmas and how brands can use these marketing paradigms to win the game of online marketing.

Keywords: Online marketing, marketing 2.0, customer reach, brand image, influential marketing, celebrity endorsement.
Published Online: January 31, 2021

ISSN: 2507-1076

DOI: $10.24018 /$ ejbmr.2021.6.1.696

Dr. Tariq Mehmood Dar *

Director Marketing \& Sales

Pharmaceuticals, UAE/Pakistan.

(e-mail: drtariqdar@gmail.com)

Ms. Neelofer Tariq

Professional Sales \& Marketing Trainer,

UAE/Pakistan.

(e-mail: neelofer.hanif@gmail.com)

*Corresponding Author

\section{INTRODUCTION}

Making a great product is not a miracle in itself, but market it effectively is the real task [1]. Marketers often confuse selling a product in exchange for money by selling a product in exchange for brand equity. Nowadays, where competition is rising globally in every industry, and each brand offers its features, advantages, and benefits (FABs), it is the mere obligation of every other brand to provide its potential customer with something more along with the product.

Whenever \& wherever the term "marketing" is mentioned, usually, the first thought that arises in the listener's mind is "Television (TV) advertisements", which are normal but mainstream at the same time. TV advertisements have always been the most effective and compelling form of marketing [2]. However, now when every single product/service is purchased online, TV advertisements are slowly losing their credibility, and the possible reasons for this dilemma are many. Digital marketing is an alternative yet operative means of smart marketing.

Digital marketing is an extended marketing paradigm on its own. Social media marketing is only a way of digital marketing [3]. The modern world includes modern problems, and thus modern solutions are required. This is why brands prefer digital marketing compared to traditional marketing because the correct way of selling or promoting a product is only acquired after analyzing the target audience's preferences and convenience. Jumping onto the easiness and frequency of people who use a smartphone is uncountable now, so internet usage is a regular practice of individuals. Thereby it is smart and quite predictable to promote products on a forum where consumers spend more than half of their day.

TV advertisements back in the day and today hold an essential aspect of marketing and considered as a longstanding way of promoting a product. In past, black and white televisions were the only source of information and entertainment [4]. The brand image sometimes depends on the advertisement on TV \& social media. Nature, size \& investment in the product hold a vitality as well. However, most of the time, audience blindly recognize everything as good, advertised on the TV through a "celebrity".

Before diving into the dilemma of which medium is better for advertising; online or traditional. It is crucial and necessary to know about the possible benefits that each of these mediums provides.

\section{A. Celebrity Endorsement}

Celebrity endorsements are an influential character to dissect for knowing how psychologically such endorsements use to and still are persuading the target audience [5]. Celebrities or influential personalities who entertain or inform people about certain things usually hold so much charisma in their personalities that no matter how they look, live, eat, smell, and all of their lifestyles [6]. Their admirers 
want to follow them, and this is the point where marketers come into the game and play with the emotional values attached to a specific personality and use this relationship to promote their products.

Marketers do so by depicting a celebrity using their particular product and raving about it and about how that specific product changed their lives. This marketing creates a ripple effect on the target audience and businesses.

Nonetheless, nowadays, when choices are uncountable and foremost when consumers are smarter than ever, it is challenging for marketers to market the correct product to the correct consumer. This is where Digital Marketing comes into handy. Though TV advertisements have lost their every green reach, the impact of celebrity endorsements has not lost their magic. Shreds of evidence exist in history where any celebrity wore a dress by any specific designer and the other day that dress used to be sold out.

The reason for this is exact, and that is that celebrity endorsements are an impactful tool for marketers to market their products. However, jumping upon to the real, quirky \& competitive times where every existing brand in the market is engaging celebrities on-board \& selling unique points of their products. Businesses who work smartly and analyze critically are taking aid from modern world "Celebrities" and "Influencers".

\section{B. Influential Marketing}

Influencers are defined to be the modern world's problem solver. These are only random individuals who chose to become "not so random" and use their quirky communication \& persuasive skills to market themselves on the internet utilizing social media Apps. Influential Marketing is relatively inexpensive compared to a traditional marketing forum and less hustling and more yielding.

Influencers post themselves as the best possible medium for a brand to market. However, niche marketing is a practical effect created when brands choose the correct influencer to market their product. Mainly because market segmentation in every era may remain the same \& target audience preference while promoting their intended product might always hold value in creating an imperative effect.

Afterward, to a brief discussion upon the modules of both online $\&$ traditional means of marketing, it is now required to address what relationship both of these concepts hypothetically have with one another. To correctly market products, brands choose an influencer to fulfill their purpose, but this raises the question of where celebrity endorsements are now a dropped trend.

Before diving into the relationship shared by celebrities' endorsement \& influential marketing, the generic terminology of "Online Marketing" needs to be addressed here to make a smooth transition in identifying the relationship of both the marketing particulars.

\section{Online Marketing}

Marketing, which implies the use of the internet, is known as online marketing. In such marketing, social media apps, websites, blogs, and articles are the billboards for brands in which they market and promote their products [7]. Though, Online marketing in itself has a wide variety of tools that can help in online marketing effectively. Influential Marketing is the topmost \& widely used technique that brands project to market their product.

Thereby, Influencers become the ruling guides for brands who opt for online marketing, a complete win/win for any brand. As mentioned before, influencers can resonate better with the customers as they are one of them. However, brands play with customer's psychics by visualizing a celebrity practicing influential marketing, which undoubtedly returns to brands with ultimate profit and higher brand equity in the long run [8].

\section{Relationship between Celebrity Endorsement \& Influential Marketing}

Brands market their image to the target audience \& thus, not only a one-time customer is generated, but usually a lifetime connection is built with a customer. Thus, these are the provoking factors that trigger smart marketers to be perfect and cater to their market niches. To fill this loop, marketers perform an amalgamated routine of marketing and use influencers as celebrities and celebrities as influencers to market their product.

The purpose of doing both is the same, and that is to do niche marketing effectively. This is where online marketing leaps ahead of traditional marketing and using social media apps that are analytically designed to cater audience's particular needs. Lastly, the significant similarity between marketing means that they target niches \& create an effect rapidly and effectively.

However, celebrity endorsement and influential marketing, both techniques are being used in the current era for online marketing and work hand in hand to provide the purpose.

\section{RESEARCH OBJECTIVES}

As discussed earlier, it becomes vital to address the impact that both celebrity endorsements \& influential marketing shades upon online marketing. Thus, the following review article will examine the fact that:

- Whether celebrity endorsements and influential marketing have changed the way of online marketing or not.

\section{RESEARCH METHODOLOGY}

The following research article will be reviewing 20 peerreviewed articles of the same domain. The upcoming literature will only be included from publications and journals, and the only versions of the literature will be dissected in this particular article. Past researchers from the tenure of 2000 till 2020 have been re-reviewed to enrich further this research article's variety and validity.

\section{LITERATURE REVIEW}

This portion of the review \& discussion is divided into two segments. The former segment is devoted to celebrity endorsements' impact on online marketing, and the latter segment is focused upon the influential marketing impact 
upon the same. However, to present the literature's conclusive form, a brief discussion will be carried out to align the literature reviewed findings.

\section{A. Celebrity Endorsement}

The first literature that genuinely justifies the objectivity of the following research article is Loureiro et al. [9], where the researcher dissected celebrities' behavior upon their complaint brands image. The paper was focused on how much celebrities' endorsements are useful in shaping consumers' word of mouth, leading to their purchase decisions. Thus, to quantify the intensity of the objectives, the study was divided into three parameters. Starting with the number of consumers (followers) following the celebrity, then to the behavior of the celebrity in the amongst with his/her audience, and then to the impact of celebrities' messages on social media sites in terms of consumer's (audience) engagement under their posts. The study was designed to be quantitative research.

Two hundred forty-one respondents, including both males \& females, participated in the study design. In the respondents' population size, there were 119 males, a celebrity's behavior afterward, to data analysis, the authors concluded the study by comments where females were more influenced by celebrities and their endorsed products than males (of the population size). Apart from the findings, the researchers also concluded that males were more likely to be influenced by eWOM (Electronic Word of Mouth) rather than particularly celebrity endorsements.

Likewise, Danniswara et al. [10] researched to check the impact of factors that shape consumers' potential purchase decisions on a social media platform. For the particular discourse of the research, Danniswara et al. [10] chose Instagram, as the platform from which the matter regarding research was collected. Moreover, to fulfill the research's objective narrations, questionnaires were designed, and 350 respondents were asked to fill the data collection tool. Afterwards, the collected data was cleaned through SEM, and results were concluded as Celebrity Endorsements along with eWOM referral and brand trust were found out to be the most influencing factors that shape consumers' purchase decisions who are shopping online. As a by-product to the discovered results, the study indicated that brand attachment $\&$ purchase decisions are majorly shaped by brand trust and purchase intention, respectively.

Herjanto et al. [11] conducted a study in Indonesia to affirm further the positive impact of celebrity and customers repurchase intention. The authors did so by studying two components of a brand; brand trust $\&$ brand image as a mediator in the relationship between celebrity endorsements $\&$ (re)purchase decisions of consumers. Thus, to prove the significance of the proposed study, the researchers built a hypothesis that celebrity endorsements does have an impact over (re)purchase decision.

For data collection, online surveys were conducted from 220 Indonesian respondents, and to dissect the data, a statistical analysis of Ordinary Least Square was used. The results were narrated as a celebrity is found to have a positive relationship with (re) purchase intention. However, to some extent, the brand component, brand trust, was declared to be a vital player in deviating former parties' relationship.

Apart from product enforcement, celebrities also manage to endorse destinations by depicting those destinations as their lifestyle. Likewise, Zhang et al. [12] conducted a study in a similar paradigm in which destination brand love was related to being under the influence of celebrity endorsements. The nature of the tourists' parasocial interactions such as potential \& previous visitors were selected to study as a mediating participant \& Hong Kong. Guangzhou was chosen to be the destination for data collection.

For the data analysis phase, all types of effects were studied as results were confronted on such basis. Visitors be them of any group are successful in forming a love relationship with the destination they are going to; however, brand destination experience acts as the primary ruler of such a relationship. However, in celebrities endorsing the destination brands, the parasocial interactions vary the effect's intensity. As potential visitors' expertise and credibility of the celebrity endorsing the destination brand must be higher than the other group of visitors. For previous visitors, brand destination experience \& attractiveness with the brand destination exceeds other parasocial interactions with the celebrities endorsing the brand destination.

Likewise, Fath et al. [13] researched the case study destination of New Zealand. The authors took the case of Tourism New Zealand (TZM) into consideration \& examined the impact of the tourism company initiating its social media campaign using a foreign Chinese actress. Upon dissecting the social media happening of TNZ, the authors came upon to realizations that tourists who were new to the destination of New Zealand were attracted to the destination because of the actress. However, the authors also mentioned the need for language considerations for brands who use a foreign celebrity to endorse their products.

Though the context revolves around online marketing, a study also mentions celebrity endorsements on youngsters' purchase decisions [14]. The particular study revolves around TV advertisements. Thus, it is related to a traditional module of marketing. The study was conducted in Pakistan \& Multan's geographical territory was chosen to be for data collection. After surveying 500 respondents, the authors get to know that celebrity endorsements do tend to influence youngsters, but then the overall personality of celebrity counts for the respondents. Such respondents are more likely to be influenced by endorsements endorsed by their favorite celebrities and not just any other celebrity.

A social media promoting dilemma was also cleaned \& proved by $\mathrm{Yu}$ et al. [15], where local endorsements by celebrities were tested to work on social media brands imperatively. The authors researched China, and Chinese celebrities were selected to be dissected based on their followers' parasocial interactions. The effect of endorsements was checked upon luxury items in china and upon surveying luxury brand frequent shoppers who were also much tech-savvy. It has come to existence that high prestige celebrities significantly influence luxury brand shoppers, and thus endorsement by such celebrities are only sufficient to them. This helped the authors to claim the dilemma that standardized (local) Vs. high-prestige celebrities also throw an impact on the endorsements 
campaign they perform.

Another crown in celebrity endorsements' dilemma is their effectiveness in conveying a positive message about the environment they live in. Likewise, Duthie et al. [16] performed a cross-sectional study to analyze if UK-based NGOs and welfare organizations enjoy their option of practicing conservation marketing with the help of celebrities. The researchers conducted an experimental study design by interviewing executives of NGOs and examining their past promotional campaigns. Upon analyzing further, the study concluded that UK-based NGOs exercise the tool of conservational marketing, and their customers and other audience do tend to get attracted majorly from it. Moreover, upon interviewing participants, their views were summarized as the advertisements that give the message of sustainable living eventually become effective when an attractive celebrity endorses it.

A study by Chung et al. [17] carried a new ray of light upon the phenomenon of celebrity endorsements \& its possible benefits. Chung et al. [17] diverted upon the factors that exert pressure on brands' social media pages' effectiveness. Thus, a theoretical framework was proposed with the help of parasocial relationships \& celebrity endorsements. The former was indicated as the dependent variable and the latter as the independent variable. Data was collected from 400 Korean respondents through online surveys, and results showed that parasocial interactions between celebrities \& respondents do create an imperative impact on one another. After interacting with the celebrity endorser on their social media, respondents find it more convenient $\&$ trustworthy to trust the brand (endorsed by the celebrity).

The following study is an excellent contribution for marketers \& brands who are always seeking ways to enhance their brand reach \& awareness at the same time through celebrity endorsements. Gupta et al. [18] proposed a five-dimensional construction \& validity scale through which brands can easily choose their brand's right ambassador. As through reviewing the literature, Gupta et al. [18] mentioned that it is not sufficient \& adequate to choose any celebrity endorser for your brand, but the effectiveness lies in selecting the right celebrity for endorsing your particular product. Thus, the researcher surveyed in India. In this survey, 692 respondents participated, and through which the parameters for selecting the right celebrity were briefed.

Popularity, attractiveness, trustworthiness, expertise \& relevance (PATER) were found out to be the most influential parameters for respondents which they look out for in a celebrity. Thereby, marketers who are in similar needs and are stirring to excel their online sales must conform to the PATER model of celebrity endorsements for desired results \& earn an amplified image of their brands.

With enough considerations from celebrity endorsements' literature, the following literature will now be shifting to the other marketing dimensions considered in the article, which is Influential Marketing.

\section{B. Influential Marketing}

Fore mostly, a study was presented in online marketing, which resulted in the effectiveness of influential marketing on social media platforms. Vinerean et al. [19] presented research where the researcher identified the need for social media marketing for a successful online marketing strategy for any brand. The researcher interrogated 236 social media users' online activities and identified the pattern, which made them follow a brand. Upon proposing a systematic review, the authors concluded that the main similarity that was found out amongst the participants when following a brand's social media page is the amplified impact of "Influencer" that has been raving about that brand.

This made the authors conclude that to succeed in online marketing; a brand must strategically adhere to its relevant "influencers" who indirectly bring traffic to the brand's social media page.

Moreover, Leeflang et al. [20] presented research in which the authors surveyed 777 marketing executives worldwide. Researchers came to the point where they put forward "influencers" as the ultimate solution for online/digital marketing problems. After understanding the themes in each marketing executive's answers, the authors claimed that the need for a virtual brand ambassador in the era of online marketing is vital mainly because these "Influencers" can relate to the general target audience on so many levels. This acts as a binding agent for both the brands $\&$ the influencers to engage with customers/followers conveniently and engagingly.

A core concept of viral marketing was revamped by Abadi et al. [21] in the form of a proposed study where the researcher identified the ways of maximizing the influence in viral/online/digital marketing. To fulfill the purpose, the authors identified after analyzing popular social media sites, including Facebook and Instagram, that "Influential leaders" are the ones who act as an online ambassador for the brands and aid their viral marketing tactics to exceed from every possible means. However, the study is quite outdated because it does not mention influencers' characteristics that brands should look to excel in their viral marketing.

However, Zareie et al. [22] proposed a research matter that can help brands identify the basic set of "Influential users" for them. The study fore focused mostly on the importance of influential internet users for brands. As reviewed in the literature, the authors did mention the ultimate need for an online ambassador for brands. Thereby, the study focused on solving the dilemma for brands to select the influential users for their brands \& mentioned the element of followers' amount as the sole element that brands should look out for in influential users. However, the researchers' online activity in terms of tweets, retweets, and commenting scheduling was also advised by the researchers before examining contemplating on a particular set of influential users.

An everlasting contributor to the brand image that brands earn by utilizing influential marketing is their word of mouth (WOM) rate increment eventually. Likewise, a study by Li et al. [23] was presented in a similar paradigm to help brands identify the ultimate and influential reviewers that aid in their businesses' WOM. A framework using PRM measure \& adaptive RFM model of data mining techniques was built, and the objective was achieved following it. The data collection was conducted by examining the social media sites \& thus, reviewing the design ratio of specific 
"influencers" was examined upon which results were concluded. Influencers create a comprehensive approach to WOM mainly because their platform's reach is more effective, less complicated, more customer-oriented than the brand's platform.

Likewise, Al-Garadi et al. [24] presented a model for analyzing the perfect set of influencers for any brand in general. The main motive behind such research was to highlight influencers' vitality for brands striving to expand their target audience's virtual reach. The researchers mentioned the working of OSN-Online Social Networks. They thus propagated that the right type of influencer for a brand depends on two main factors of the influencer's reach \& OSN working.

Moreover, a basic yet transparent study was presented by Freberg et al. [25], where the researchers cleared out the air and doubt related to the term "Influencers". Though the study is primary, however, it does guide the brands who are still new to the concept of digitalization. After contemplating a perceptional-based study design, the authors found out that Influencers are considered the virtual angels for brands. They are way less expensive than proper traditional marketing techniques. Foremost, influential marketing is about applying a brand's reach from its target customers to its potential customers. Thus, influencers and influential marketing are quite a blessing for brands searching for virtual life.

Goodman et al. [26] proposed a means of identifying "influencers" for businesses because mainly the researchers initiated the study on the systematic review of the already existing vitality of "influencers", and as per the researcher, it is not essential to identify that who are these "influencing people". Through a customized algorithm module, the author realized that influencers amongst the customers are the ones who optimize the internet in a better $\&$ fruitful way to showcase their talent. Further, the study recommended that influential marketing, if revamped effectively, can omit the traditional marketing techniques completely.

Abidin et al. [27] proved through their research that Influential marketing is the future of brands as the coming era will be all about digitalization. The study was proposed in Singapore, where female influencers" "outfit of the day" trend was taken as semantic proof for followers who are getting influenced by influencers' dressing. After reviewing ethnographic fieldwork on Instagram, the researcher concluded that influencers are walking talking billboards \& if utilized properly, they can revolutionize the marketing industry mainly because their influencing power is spectacular.

Lastly, Cuevas et al. [28] proved through a systematic review that influencers act as the human brands for consumers \& do nothing but make or break the brand's image. The researchers concluded that influencers successfully manage to build a heart-warming connection with the general audience because they become transparent with the audience. Thereby, the study summarized the use of influencers as a win-win strategy for brands \& their virtual communities.

\section{CONCLUSION}

The reviewed literature implies the extravagant benefits that any brand can avail if it uses influential marketing \& celebrity endorsements smartly. The term smartly' here entails quick results for a comparatively longer time. The following research's objectified statement is also filled with the help of reviewed articles \& the dilemma of marketing under consideration, primarily helping a brand change their game of online marketing. Though the literature majorly focuses upon how imperative influential marketing is in the era of digitalization, it does not in any way omits the impact of evergreen celebrity endorsement for the customer. However, the literature can be aimed as a filling material and competently fill the loophole of lacking awareness about the mediums mentioned above.

Marketers who prefer to work by traditional means of marketing may be growing in terms of sales growth. However, the question raised here is that growth longevity enough? The answer is No. Mainly, the era of technology gets to decide what will run and what will boom. Presently, only brands that have active social media are successful enough to generate virtual communities.

Moreover, these virtual communities of brands are a product of the brand's influences, and they could be celebrities as well.

\section{RECOMMENDATIONS}

Though the concept of both influential marketing \& celebrity endorsements is hypothetical and practically giving the brands everything, including success, the following considerations must be taken to flourish the future parameters of marketing further globally.

- Brands should also have a complete marketing and promotional plan for digital media along with the other traditional different platforms. Brands should opt for branding through influencers on their virtual platforms.

- Influential marketing can also consist of 'celebrity endorsements', so the brand must opt for taking it that way, choosing influencers or celebrities as per their convenience $\&$ relevance.

- Influential marketing is a cost-effective means of marketing, plus the reach of this marketing is more expanded and effective than traditional marketing.

- Celebrity endorsement is the marketing strategy that can be further exceeded by amalgamating with influential marketing. It all depends upon the marketing module of the brand and how they are treating their online presence.

- Gone are the times when products were made to cater to customers' needs. The current era is vice versa. Thereby, with influencers' help, brands can aid their persuasive powers \& understand their target audience from a little less distance.

\section{SUMMARY}

The concluded research article is presented to make marketers aware that if they lack in building virtual communities of their brands, then the two major things they 
should quickly opt for are celebrity endorsements \& influential marketing. Benefits and importance regarding those mentioned above are entitled in the article to get the reader's better understanding of online marketing.

\section{REFERENCES}

[1] Erdogan, B. Zafer. "Celebrity endorsement: A literature review." Journal of marketing management 15, no. 4 (1999): 291-314.

[2] Kotler, Philip. Kotler on marketing. Simon and Schuster, 2012.

[3] Strauss, Judy, and Raymond Frost. E-marketing. Prentice hall press, 2008 .

[4] McCarthy, Edmund Jerome, Stanley J. Shapiro, and William D. Perreault. Basic marketing. Ontario: Irwin-Dorsey, 1979.

[5] Abimbola, Temi, Ming Lim, Elina Halonen-Knight, and Leila Hurmerinta. "Who endorses whom? Meanings transfer in celebrity endorsement." Journal of Product \& Brand Management (2010).

[6] Byrne, Angela, Maureen Whitehead, and Steven Breen. "The naked truth of celebrity endorsement." British Food Journal (2003).

[7] Rose, Robert, Nichole Goodyear, Camille Matthews, Jeremy Wiles, Mark Seaman, Brian Douglas Derfer, Kevin Rollins, Kelvin Hung, and Gina Paoni. "Online marketing platform." U.S. Patent 8,788,334, issued July 22, 2014.

[8] Kingsnorth, Simon. Digital marketing strategy: an integrated approach to online marketing. Kogan Page Publishers, 2019.

[9] Loureiro, Sandra Maria Correia, and Eduardo Moraes Sarmento. "The role of word-of-mouth and celebrity endorsement in online consumer-brand relationship: the context of Instagram." The role of word-of-mouth and celebrity endorsement in online consumer-brand relationship: the context of Instagram (2018): 1119-1129.

[10] Danniswara, Randy, Puspa Sandhyaduhita, and Qorib Munajat. "The impact of EWOM referral, celebrity endorsement, and information quality on purchase decision: A case of Instagram." In Global Branding: Breakthroughs in Research and Practice, pp. 882-905. IGI Global, 2020.

[11] Herjanto, Halimin, Michael Adiwijaya, Elizabeth Wijaya, and Hatane Semuel. "The Effect of Celebrity Endorsement on Instagram Fashion Purchase Intention: The Evidence from Indonesia." PhD diss., Petra Christian University, 2020.

[12] Zhang, Hui, Honggang $\mathrm{Xu}$, and Dogan Gursoy. "The effect of celebrity endorsement on destination brand love: A comparison of previous visitors and potential tourists." Journal of Destination Marketing \& Management 17 (2020): 100454.

[13] Fath, Benjamin P., Antje Fiedler, Zixuan Li, and D. Hugh Whittaker. "Collective destination marketing in China: Leveraging social media celebrity endorsement." Tourism Analysis 22, no. 3 (2017): 377-387.

[14] Raza, Syed, Sannan Waheed Khan, and Aqsa Irum. "Relationship of the Celebrity Endorsement in the TV-Advertisements and Buying Behavior of Youth." New Media and Mass Communication 52 (2016): 22-28.

[15] Yu, Shubin, and Yangjuan Hu. "When luxury brands meet China: The effect of localized celebrity endorsements in social media marketing." Journal of Retailing and Consumer Services 54 (2020): 102010.

[16] Duthie, Elizabeth, Diogo Veríssimo, Aidan Keane, and Andrew T. Knight. "The effectiveness of celebrities in conservation marketing." PloS one 12, no. 7 (2017): e0180027

[17] Chung, Siyoung, and Hichang Cho. "Fostering parasocial relationships with celebrities on social media: Implications for celebrity endorsement." Psychology \& Marketing 34, no. 4 (2017): 481-495.

[18] Gupta, Ruchi, Nawal Kishor, and D. P. S. Verma. "Construction and validation of a five-dimensional celebrity endorsement scale: introducing the pater model." British journal of marketing studies 5, no. 4 (2017): 15-35.

[19] Vinerean, Simona, Iuliana Cetina, Luigi Dumitrescu, and Mihai Tichindelean. "The effects of social media marketing on online consumer behavior." International Journal of Business and Management 8, no. 14 (2013): 66.

[20] Leeflang, Peter SH, Peter C. Verhoef, Peter Dahlström, and Tjark Freundt. "Challenges and solutions for marketing in a digital era." European management journal 32, no. 1 (2014): 1-12.

[21] Abadi, Neda Salehi Najaf, and Mohammad Reza Khayyambashi. "Influence maximization in viral marketing with expert and influential leader discovery approach." In 8th International Conference on e-Commerce in Developing Countries: With Focus on e-Trust, pp. 1-8. IEEE, 2014.
[22] Zareie, Ahmad, Amir Sheikhahmadi, and Mahdi Jalili. "Identification of influential users in social networks based on users', interest.” Information Sciences 493 (2019): 217-231.

[23] Li, Yung-Ming, Chia-Hao Lin, and Cheng-Yang Lai. "Identifying influential reviewers for word-of-mouth marketing." Electronic Commerce Research and Applications 9, no. 4 (2010): 294-304.

[24] Al-Garadi, Mohammed Ali, Kasturi Dewi Varathan, Sri Devi Ravana, Ejaz Ahmed, Ghulam Mujtaba, Muhammad Usman Shahid Khan, and Samee U. Khan. "Analysis of online social network connections for identification of influential users: Survey and open research issues." ACM Computing Surveys (CSUR) 51, no. 1 (2018): 1-37.

[25] Freberg, Karen, Kristin Graham, Karen McGaughey, and Laura A Freberg. "Who are the social media influencers? A study of public perceptions of personality." Public Relations Review 37, no. 1 (2011): 90-92.

[26] Goodman, Michael B., Norman Booth, and Julie Ann Matic. "Mapping and leveraging influencers in social media to shape corporate brand perceptions." Corporate Communications: An International Journal (2011).

[27] Abidin, Crystal. "Visibility labour: Engaging with Influencers' fashion brands and\# OOTD advertorial campaigns on Instagram." Media International Australia 161, no. 1 (2016): 86-100.

[28] Cuevas, Leslie M., Sze Man Chong, and Heejin Lim. "Influencer marketing: Social media influencers as human brands attaching to followers and yielding positive marketing results by fulfilling needs." Journal of Retailing and Consumer Services 55 (2020): 102133.

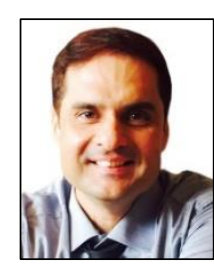

Tariq Mehmood Dar is a medical doctor. He earned his MBBS degree from Dow Medical College, Karachi University, Pakistan. He did his postgraduation in Diabetology. Dr. Tariq is a Clinical Research Certified Professional. He also holds an MBA degree specialization in sales \& marketing. He has more than 15 years of sales and marketing experience in pharmaceutical industry in Pakistan \& UAE. He worked at different position in the pharmaceuticals from medical representatives to marketing head.

Currently, he holds a position of Director Marketing \& Sales in a multinational pharmaceutical company based at UAE.

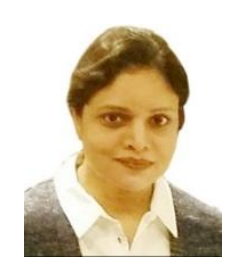

Neelofer Tariq is a professional pharmacist and seasoned marketer. She is a Doctor of Pharmacy. She earned Doctor of Pharmacy degree from Karachi University, Pakistan. She also holds an MBA degree with specialization in Pharmaceutical Marketing \& Health Management.

She is a professional sales and marketing trainer and holds more than 10 years' experience in the pharmaceutical industry of Pakistan/UAE. 